\title{
(6) OPEN ACCESS \\ Lessons from the organisation of the UK medical services deployed in support of Operation TELIC (Iraq) and Operation HERRICK (Afghanistan)
}

\author{
Martin C M Bricknell, ${ }^{1}$ M Nadin ${ }^{2}$
}

${ }^{1}$ Ministry of Defence, Director Medical Policy and Operational Capability, Whitehall, London, UK

${ }^{2}$ Capability Directorate (Army), Formerly Head of Medical Capability (Army), Andover, UK

Correspondence to Maj Gen Martin C Bricknell, Director Medical Policy and Operational Capability, Ministry of Defence, Whitehall, SW1A $2 \mathrm{HB}$ London, UK; martin@bricknell.net

Received 17 September 2016 Revised 5 November 2016 Accepted 8 November 2016 Published Online First 6 January 2017

\section{ABSTRACT}

This paper provides the definitive record of the UK Defence Medical Services (DMS) lessons from the organisation of medical services in support of Operation (Op) TELIC (Iraq) and Op HERRICK (Afghanistan). The analysis involved a detailed review of the published academic literature, internal post-operational tour reports and posttour interviews. The list of lessons was reviewed through three Military Judgement Panel cycles producing the single synthesis 'the golden thread' and eight 'silver bullets' as themes to institutionalise the learning to deliver the golden thread. One additional theme, mentoring indigenous healthcare systems and providers, emerged as a completely new capability requirement. The DMS has established a programme of work to implement these lessons.

\section{INTRODUCTION}

This paper provides a summary of lessons from the organisation of medical services in support of Operation (Op) TELIC (Iraq) and Op HERRICK (Afghanistan) covering the period from February 2003 to November 2014. The achievement of the best possible clinical outcomes for our patients was the product of synergy between the chain of command, medical organisation and excellent clinical practice. This paper, by interpreting how medical services were organised, complements the clinical lessons that are the main feature of the multiple academic publications by Defence Medical Services (DMS) clinicians.

\section{SCOPE AND METHOD}

This paper is based on material already in the public domain, primarily scholarly articles already published in medical journals, however other government publications have been cited, notably those produced by Defence Statistics (Health). No new primary research has been undertaken and thus the evidence set is affected by the relative paucity of material on the DMS organisation in Iraq compared with Afghanistan. The focus is on deployed medical services and does not capture the lessons from providing healthcare for wounded, sick or injured service personnel from these operations after their return to the UK in the Role 4 pathway. Lessons published by other nations from within the military coalition in both theatres or from the clinical care of Iraqi or Afghan casualties are not considered.

This article is structured around the medical lessons at Chapter 4-2 of the Op HERRICK

\section{Key messages}

- The Journal of the Royal Army Medical Corps has provided a longitudinal record of lessons for military medicine since first publication.

- This paper is an official statement of the organisational lessons from Operation (Op) TELIC and Op HERRICK for the Defence Medical Services.

- This paper lists the activities being undertaken to implement these lessons.

Campaign Study published in March 2015; a redacted version of this document was released to the public domain in January 2016 as a result of a Freedom of Information request. ${ }^{1}$ The Health Services Support element of the study was tasked directly to the Army Medical Directorate, but a Joint approach was adopted and the breadth of the DMS were consulted and participated in the analysis, including significant contributions through the Defence Consultant Advisors (DCAs) and Professors, the medical staffs in the operational headquarters and both Royal Navy and Royal Air Force Medical Services. While undertaken towards the end of Op HERRICK, the analysis represented a culmination of organisational knowledge accrued over the preceding decade.

The analysis was initiated with a literature review, focused on Op HERRICK post-operational reports, Commanders' post-operational interview transcripts and articles published within peerreviewed journals. Several hundred lessons and observations were assimilated and circulated for review by a DMS-wide audience that included the DCAs and Professors, who were requested to add their own lessons and observations. Further consolidation followed, leading to a Joint senior level Military Judgement Panel (MJP), which reviewed 240 lessons, identified the top third and consolidated these into 23 lessons and themes. The 23 lessons were forwarded for consideration by a selected panel of 40 Op HERRICK medical Subject Matter Experts (SME), who were individuals who held Op HERRICK assignments as a Commander Medical, Deployed Medical Director, Brigade Senior Medical Officer, Commanding Officer (CO) of the Bastion Role 3 Hospital or the medical regiment, DCAs, Defence Professors, CO of the Royal Centre for Defence Medicine, North Atlantic Treaty Organization (NATO) Medical Adviser and 
principal Joint and single Service Medical Staff Officers. These senior individuals had all completed Op HERRICK-related assignments and were requested to provide insights based on their own Op HERRICK experiences. Given the length of the campaign, many had undertaken multiple deployments on Op HERRICK and also undertaken assignments in direct support of the operation. Thirty SMEs responded, producing 80 additional insights and observations, bringing significant richness to the data and permitting detailed triangulation of lessons and practices. The insights and observations were mapped against the 23 lessons and taken forward for consideration by a senior six member MJP. This panel reviewed the lessons and made further consolidation, resulting in the list contained herein that are definitive lessons of the DMS.

The principal insight is based on a narrative from the multitude of lessons, observations and insights that encapsulates the UK military medical endeavour and development over 8 years. The MJP also identified nine themes that require actions or work to retain, institutionalise or support this narrative. Each individual theme has been amplified by reference to academic papers published in the public domain and the method for subsequent implementation of these lessons into changes to organisation or practice is summarised in italics.

\section{THE NARRATIVE: THE SYNTHESIS OF LESSONS, OBSERVATIONS AND INSIGHTS}

The standard of healthcare delivered on Op TELIC and Op HERRICK, and resultant patient outcomes, provides the baseline that the DMS aspire to deliver on future operations. This performance was the result of the Operational Patient Care Pathway $(\mathrm{OPCP})^{2}$ being managed as a single and coherent end-to-end healthcare system, from point of injury to the home base (Role 4). There is robust clinical evidence of cumulative improvement in the probability of survival of the UK military casualties $^{3}$ and the trauma system was regarded as exemplary by the Care Quality Commission. ${ }^{4}$ It is recognised however, that constraints (political, operational, tactical and financial) may prevent its future achievement. Should such risk be identified by medical planners, it must be highlighted to operational commanders in order that it is properly mitigated, or tolerated as an explicit decision.

The DMS OPCP uses consultant delivered healthcare as routine, which is an enhancement over the UK NHS practice. It specifically encourages rapid and effective decision making and exploits senior clinical leadership for every seriously injured patient-expressed quite simply, 'seniority saves lives'. The evolution of that 'end-to-end' system arose from developments in clinical concepts, practice and governance that have been described in the medical literature relating to the medical experience in Iraq and Afghanistan. These step changes arose from a combination of detailed scrutiny of every serious injury or fatality, an improved understanding of wounding mechanisms and pathophysiology and research into the treatment of blast and ballistic trauma. This has driven advances in personal and vehicle protective systems alongside the training and education of deploying clinicians and the development of innovative clinical practices. Financial investment led to better clinical infrastructure, clinical equipment (diagnostic and treatment) and greater availability of medical evacuation (MEDEVAC) helicopters crewed with physician-led patient retrieval teams. The NHS played a vital role in the partnered provision of Role 4 healthcare for military casualties on return to the UK, with importantly, Defence also providing uniformed administrative and welfare support within the Queen Elizabeth Hospital,
Birmingham. The NHS remains a key strategic partner for the Ministry of Defence (MOD) to maintain an appropriately prepared pool of military secondary healthcare (SHC) staff at readiness to deploy on operations.

These clinical gains were underpinned by significant enhancements in training, equipment and MEDEVAC. Such enhancements may not be available during the early stages of future operations because of constraints on our ability to move medical mass; competing priorities for use of helicopters may restrict their availability for MEDEVAC and the current limited environmental tolerance of some key clinical equipment. These enhancements within a new theatre of operations will have to be built incrementally as the capacity of the Joint Supply Chain allows and the theatre matures. Consequently, our clinical research should be directed towards the following goals:

- The development of miniaturised and ruggedised imaging and laboratory capability that has better tactical transportability and environmental tolerance and reduces logistic drag, and which may offer the use of imaging and laboratory support forward of field hospitals.

- The development of clinical interventions and protocols that enhance our ability to sustain patients more effectively during prolonged field care if medical planning timelines cannot be met.

The primary organisational lessons have been captured in the new concept - the Operational Patient Care Pathway. This has been incorporated into medical doctrine, and the UK national medical doctrine has been merged with NATO medical doctrine as a single publication. ${ }^{5}$

\section{MEDICAL STATISTICS AND WORKLOAD}

Data are essential to the analysis of performance of any medical system. The military medical system is unique in that it operates under single organisational direction and so it is possible to direct the collection and collation of medical information from point of wounding to ultimate retirement of a service person. The system for collating the routine, paper-based reports from medical units that provided the basis for the medical statistics volumes of the Official Histories for the First and Second World Wars ${ }^{6}{ }^{7}$ had decayed to such an extent that in 2003 there was no single institutional mechanism for the collation of medical data from operations. The collection of data to support the statistical and epidemiological evidence of the performance of the military health system evolved during the two campaigns. Initially the data were presented as case series collated by medical personnel during their operational tours in individual medical units. ${ }^{8-10}$ This evolved into systematic data collection based on the Operational Emergency Department Admission Record, in which the data from all admission log books from field hospitals were collated into a single electronic database thus creating the first registry of all admissions to field hospitals. ${ }^{11}$ Data on all trauma cases admitted to field hospitals were captured in a standardised data form and incorporated into the Joint Theatre Trauma Register (JTTR), ${ }^{12}$ which was initially managed by RCDM, but as the requirement for MOD official medical statistics emerged, the JTTR transferred to Defence Statistics (Health). The JTTR has provided a rich source of data for analysis, including analysis of those who died of their wounds, ${ }^{13}$ the management of paediatric casualties, ${ }^{14}$ the use of tourniquets, ${ }^{15}$ outcomes from massive blood transfusion ${ }^{16}$ and to benchmark clinical outcomes against the UK national performance data. ${ }^{17}$

Defence Statistics (Health) developed further datasets to capture information on military casualties including the 
Defence Patient Tracking System, the Complex Trauma Database and the Prosthetics Database. Additional information on the performance on the military health system has been derived from the Wounded, Injured and Sick Management Information System, the notification of casualties system and the Joint Personnel Administration system. From these datasets, Defence Statistics (Health) has produced a series of publications that capture the statistical record of the deaths, injuries and medical care episodes from Op TELIC and Op HERRICK.

There were 178 deaths (135 due to hostile action and 43 from other causes) and 17 traumatic amputations during Op TELIC and 456 deaths $(405,51) / 275$ amputations during Op HERRICK. ${ }^{18} 19$ There is no specific analysis of field hospital activity for Op TELIC, but from the opening of the UK field hospital in Afghanistan on 1 April 2006 until the closure of Op HERRICK on 30 November 2014, 7800 UK service personnel and civilians were admitted to a field hospital; 7601 of these were the UK service personnel of which 4220 were the result of injuries and 3347 the result of natural causes. Of the 4220 admissions, approximately half were battle injuries (BI) and half were non-battle injuries (NBI). Just under half (1982) of the patients admitted to the field hospital with injuries required the activation of the UK trauma team and approximately half of the injuries sustained by the UK Armed Forces trauma patients were to the extremities, with the largest number of injuries sustained to the knee and lower leg. Injuries to the head and neck accounted for just under a fifth of the injuries sustained. Within each of the injury categories, open wounds, fractures and fragmentation/shrapnel wounds were the most common types of injury regardless of the body region affected. Explosions (which include improvised explosive devices and mines) were the leading mechanism of injury for BI, followed by small arms fire (which includes gunshot wounds and grenades). There were also a small proportion of personnel injured by explosions and small arms fire that were NBI injuries, such as negligent discharge. NBI comprised a range of mechanism of injury including climatic injuries, land transport accidents and slips, trips and falls. $^{20}$

These data collection systems have been generalised for all future operations. Alongside the JTTR, the DMS is developing datasets to capture the hospital workload from disease and NBI.

\section{THE NINE THEMES REQUIRED TO INSTITUTIONALISE, RETAIN OR SUPPORT THE NARRATIVE}

The medical lessons analysis developed eight specific themes that require further work to institutionalise, retain or support the golden thread. These too are a synthesis of all the recorded lessons and insights, and impact on the totality of the OPCP and within the capabilities of operational healthcare defined in medical doctrine. They are set out below and are not prioritised.

The medical command and control structure must be appropriately resourced to be effective

The medical command and control (C2) structure provides medical planning, technical medical advice and governance of the medical system to the chain of command. ${ }^{21}$ It is essential that there is a clear relationship for technical command of the medical function throughout the formal military command structure. $^{22}$ The initial deployment on Op TELIC had a full complement of medical staff embedded in every headquarters from Brigade to Theatre level. This rapidly drew down into a unified medical group with a medical staff branch in the commanding Divisional headquarters. On Op HERRICK, from 2006 to 2009 a single lieutenant colonel CO was responsible for the entirety of deployed medical provision. The $\mathrm{CO}$ was required to command tactically both a Role 3 Hospital and a medical regiment and fulfil the role and responsibilities of a theatre commander medical. This led to conflicts of interest, a tactical focus to the CO's area of responsibility and an inability to step back, take an overview and rebalance medical resources and effort effectively. From the middle of 2009, this function was separated with a UK theatre commander medical within the Headquarters Joint Force Support and independent subordinate commands for the medical regiment and the hospital. The NATO command structure had a medical staff branch in every headquarters, although the medical adviser had limited formal authority over medical units in Afghanistan because the majority were national assets. ${ }^{23}$

It is essential that personnel assigned to the medical C2 structure are properly trained for their role. This includes knowledge of the medical contribution to the estimate process, ${ }^{24} 25$ methods to undertake casualty estimation ${ }^{26} 27$ and the methods to manage the coordination of medical care on the battlefield. ${ }^{28}$ The assessment of the performance of the medical system is a critical function. This is based on the dataset described in the section on medical statistics and workload which should provide an active feedback loop. ${ }^{29}$ It is likely to be augmented by in-theatre datasets such as operational health surveillance systems. $^{30}$

The intensity of clinical operations in the hospital at Camp BASTION on Op HERRICK demonstrated the need for a clear clinical leadership function alongside the $\mathrm{CO}$ of the hospital. This role developed into the Deployed Medical Director post as formal appointment for the senior clinician that was separate from a clinical consultant appointment. ${ }^{31}$ This post became essential in leading the clinical team through challenging ethical dilemmas in the provision of clinical care and the allocation of clinical resources, particularly in the care of Afghan civilian casualties. $^{32} 33$

The requirement for clear medical C2 is explicit in Allied Joint Medical Doctrine. The DMD role is established in all deployable hospital units.

\section{Develop multinational healthcare interoperability}

Multinational medical provision on operations offers the advantage of burden sharing between nations whose military forces are sharing an operational area. ${ }^{23} 34$ Since 2009, the Bastion Role 3 Hospital has demonstrated that a multinational-staffed facility can deliver exceptional patient outcomes. This was based on a Lead Nation defined through a formal Technical Arrangement. ${ }^{35}$ This confirmed the UK command, the use of DMS clinical protocols and made the hospital subject to DMS Healthcare Governance and Assurance. Predictable cultural and clinical differences between nations were partially mitigated through combined training during the Role 3 Hospital's Mission Specific Validation (MSV). However, to ensure we deliver the required quality of healthcare during the early stages of future operations, we must invest in understanding potential medical partners by developing and sharing with them our clinical practices and protocols.

The Strategic Defence and Security Review 2016 emphasised the importance of alliances and coalitions. The DMS future international medical engagement strategy emphasises interoperability in our partnership with alliance nations and is being delivered through a programme of multinational combined exercises and exchange visits. 
Develop healthcare record management and information exchange/management functionality

The section on medical statistics and workload emphasises the need for active management of healthcare records across the OPCP. While strategic policy exists, experience on Op HERRICK showed that a significant number of DMS staff did not understand, or were unaware of the individual and corporate responsibilities (statutory, professional and ethical) associated with healthcare records. ${ }^{36}$ This needs to be addressed through more structured and didactic education of DMS personnel. Better medical information systems (MIS) are required to ensure the fidelity and timeliness of the transfer of primary healthcare records to and from theatre, and that episodes of DHC are captured with the required accuracy. ${ }^{37}$ We must be able to exploit clinical data more effectively. This has particular significance with regard to force generation to prevent the deployment of individuals with inappropriate medical conditions. ${ }^{38}$ The DMS also needs to be able to communicate and transfer data, including clinical data to conduct patient transfer between the UK roles of healthcare, theatre and the Firm Base and with indigenous, coalition, international agency and non-government organisation healthcare providers. ${ }^{39} 40$

The MOD is investing in future MIS under the title of programme CORTISONE, ${ }^{41}$ which will address these issues.

\section{Battlespace headquarters require clinical decision support for effective patient regulation}

This lesson builds on the lesson concerning healthcare records and information management. The Patient Evacuation Control Cell (PECC) is the critical component of the medical system that controls medical evacuation to ensure that the right patient has the right clinical escort, is transported in the right platform to the right destination in the right time for their clinical condition. ${ }^{42}$ Effective MEDEVAC tasking requires clinically qualified personnel to provide medical advice to the 'ambulance despatch function' on behalf of the battlespace commander who authorises the assignment and movement of MEDEVAC platforms, particularly when multiple MEDEVAC capabilities are available. ${ }^{43}$ The PECC must be collocated within the Joint Operations Centre (or equivalent) that tasks and authorises the execution of MEDEVAC missions to provide necessary situational awareness of the battlefield environment.

These recommendations are explicit in Allied Joint Medical Doctrine.

\section{Exploit our expertise and experience in Role 3 training}

validation to develop a comparable Role 1 process

Role 3 collective training has been institutionalised and appropriately resourced through a macrosimulation hospital exercise (HOSPEX), which is a formal field training exercise with supporting assessment methodologies including MSV. The utility and benefits of HOSPEX have been demonstrated by postdeployment and post-operational reports. It provides the exemplar process for delivery and assurance of the military field hospital system before deployment and has facilitated the integration and orientation of multinational staff elements into the UK practice. It is supported by a detailed, reproducible and auditable mechanism of assuring and validating the hospital capability. The detail of HOSPEX was covered in a themed edition of the Journal of the Royal Army Medical Corps in $2008 .{ }^{44}$ This system has been replicated by other nations ${ }^{45}$ and was critical to the safe operation of the DMS Ebola Virus Treatment Facility that was deployed to Sierra Leone in 2014. ${ }^{46}$
However, the method for Role 1 collective training and validation was less institutionalised and less well resourced during the Op TELIC/HERRICK period. ${ }^{47} 48$ The lessons analysis identified the requirement to bring coherence and commonality to the assessment and validation of pre-hospital care and deployed hospital care collective training so they become a single effective quality assurance process. ${ }^{49}$ This requires a method to validate contingent medical capability effectively across the OPCP and thereby provide the assurance it is capable of delivering the required standard of healthcare throughout the system. ${ }^{50}$ Following completion of the specific medical collective training, medical units must also undertake generic collective training with the formations they will support in order to integrate and function effectively on the common battlefield. ${ }^{51}$

All three services are developing pre-hospital care clinical validation centres in which individuals and teams can have their military and clinical skills assessed on a periodic basis.

The increasing relevance of military competencies

During Op TELIC and Op HERRICK, the majority of DMS personnel, and in particular deployed hospital care staff, deployed into a mature theatre with well-founded clinical, technical and living accommodation. They were not required to use military skills such as counter-CBRN (chemical, biological, radiological and nuclear), countersurveillance and tactical movement. Military skills will have increased relevance during future operations and will be required of clinical staff to enable them to deliver clinical care in the Future Operating Environment. ${ }^{52} 53$ Individual competence must be demonstrated through completion of Mandatory Army Training Tests or the equivalent test for Royal Navy or Royal Air Force. Clinical staff must regularly practise these competencies together in order to be ready for short notice deployment.

Each service has mandatory predeployment training standards. Individual's clinical performance is assessed during predeployment validation.

\section{Regularise Combat Medical Technician clinical exposure} within the Firm Base

Throughout Op TELIC and Op HERRICK, Army Combat Medical Technicians (and their Royal Navy and Royal Air Force equivalents) have demonstrated pre-hospital trauma skills but the evidence of high-quality performance has not been strong ${ }^{54}$ and they have been relatively weak in providing primary healthcare. ${ }^{55-57}$ This is systemic and due to the challenge of providing them with appropriate pre-deployment clinical exposure within the Firm Base to develop the clinical experience and currency to deliver high-quality pre-hospital healthcare on operations. The requirement for appropriate clinical exposure must be formalised and regularised. ${ }^{58}$

A new programme, the Defence Medic, has been introduced to ensure military medics are trained to the same standard as their NHS equivalent and to enable clinical placements within NHS ambulance trusts and MOD medical centres.

\section{Train to treat the entire operational patient suite}

Op TELIC and Op HERRICK again demonstrated the diversity and complexity of the patient population that required, and will require, treatment on future operations within the UK medical treatment facilities. There has been a continuous series of reports that emphasise the requirement to have the skills and clinical equipment to provide appropriate clinical care for paediatric patients. ${ }^{14}$ 59-61 The nature of the counterinsurgency 
campaigns on both operations also required the DMS to provide clinical care for captured persons (CPERS). ${ }^{62} 63$ The legal, ethical and clinical considerations for providing medical support to CPERS proved to be so fundamentally different to normal clinical practice that it was necessary to develop special training in this subject and establish specific governance arrangements to comply with International Humanitarian Law. ${ }^{64}$

The DMS should be capable of providing appropriate clinical care to the breadth of the defence population at risk that is explicit in Allied Joint Medical Doctrine.

Mentoring indigenous healthcare systems and providers: the medical contribution to wider campaign effects

The goal for an international counterinsurgency campaign is to create the conditions for the indigenous government to have sufficient political and military power to manage their own security challenges. This is captured under by the concept of Security Sector Reform, with an inevitable requirement to ensure that the medical support to the indigenous security services is sufficient to maintain the moral component of their fighting power. ${ }^{65}$ While there was limited medical mentoring for the Iraqi security forces in Basra, there is no record of a systematic plan in the public domain. In Afghanistan, medical mentoring within 215 Corps (the Afghan National Army (ANA) unit in Helmand) was limited to Combat Lifesaver training and tactical casualty evacuation training until late 2012. At that point, it was recognised that an Afghan hospital facility was required to replace the Bastion Role 3 hospital in order to sustain the ANA's will to fight. This could not be collocated with the Afghan civilian hospital in the provincial centre in Lashkar Gar due to security concerns. The UK provided the significant majority of the hospital medical mentors to support the establishment of an ANA surgical capability and treatment facility in the 215 Corps main operating base. The experience of supporting health sector development for the ANA recognises that this requires specific knowledge based on a deep understanding of the organisation of military medical services across a wide range of political and economic environments. ${ }^{66} 67$

Military medical services may also be a significant international contribution to the overall medical resources in a complex emergency, ${ }^{68}$ however, there are recognised constraints on the use of international medical forces in providing direct medical care to the indigenous community, particularly outside of hospital care. ${ }^{69}$ It is important for medical planners to carefully consider all possible consequences before committing to medical civilian aid programmes (MEDCAPs). ${ }^{70}{ }^{71}$ Military medical services may be better focused on clinical training and organisational advice alongside the wider international community if there is a requirement to support civilian health sector development.

This experience demonstrated the significance of the effect medical mentorship can have in contributing to the development of indigenous health sectors. The effect is applicable as part of a stabilisation operation and is also eminently suitable as a discrete, politically low-risk and publicly supportable contribution to our Defence Engagement strategy. The DMS must establish as a core competence, the development of indigenous security forces' medical services within the wider military task of upstream capacity building within a Joint Interagency Intergovernmental Multinational approach.

These requirements have been captured in a Joint Doctrine Note titled 'The Military Medical Contribution to Security and
Stabilisation, ${ }^{72}$ Strategic Defence and Security Review (SDSR) 2016 funded the creation of a Centre for Defence Healthcare Engagement to act as a focus for lessons and training in this area.

\section{TRANSFERRED LESSONS}

In addition to the organisational lessons described above, the analysis identified four additional themes that require action in consultation with wider stakeholders. While the medical services provide technical advice on Force Health Protection, it is the engineer branch that sets the requirement for Expeditionary Campaign Infrastructure (ECI). This must have appropriate field sanitation and hygiene equipment in order to minimise transmissible disease risks. Medical logistics underpins all medical care. However, in the UK, medical logistics is considered to be a subordinate task of the logistic services. The medical supply chain must be robust, effective and efficient, managed by personnel with relevant experience and underpinned by endorsed medical supply doctrine. Aligned to this, the medical services require the logisticians to deliver a robust and effective mechanism, underpinned by policy, for clinical waste management from all clinical facilities during contingency operations. Finally, many lessons were learned about providing sensitive and effective mortuary services including repatriation arrangements, clinical support to inquests and providing a feedback loop to improve the physical protection of service personnel from ballistic threats. $^{73-75}$

\section{LOOKING TO THE FUTURE}

This paper provides the definitive record of the organisational lessons learned by the Defence Medical Services from the campaigns in Iraq and Afghanistan. We have a duty to our patients to ensure that we continue the same standard of professional inquiry into the performance and evolution of the military medical system for all future military operations. This has been reflected in the DMS approach to capture the lessons from our contribution to the international response to the Ebola crisis, Op GRITROCK. ${ }^{76}$ Between operations, we must ensure that operational experience is transferred across generations and that we constantly test our assertions against developments in clinical practice in the civilian sector and the experience of other nations on military operations. Our concepts and doctrine need to be continually reviewed and communicated to our DMS personnel. ${ }^{77}$

Contributors This article was conceived and written by both authors. MCMB is the guarantor.

Competing interests None declared.

Provenance and peer review Not commissioned; externally peer reviewed.

Open Access This is an Open Access article distributed in accordance with the Creative Commons Attribution Non Commercial (CC BY-NC 4.0) license, which permits others to distribute, remix, adapt, build upon this work non-commercially, and license their derivative works on different terms, provided the original work is properly cited and the use is non-commercial. See: http://creativecommons.org/ licenses/by-nc/4.0/

\section{REFERENCES}

1 Army Land Warfare Centre. OP HERRICK Campaign Study. http://www.gov.uk/ government/uploads/system/uploads/attachment_data/file/492757/ 20160107115638.pdf

2 Bricknell MCM. For debate: the operational patient care pathway. J R Army Med Corps 2014;160:164-9.

3 Penn-Barwell JG, Roberts SAG, Midwinter MJ, et al. Improved survival in UK combat casualties from Iraq and Afghanistan: 2003-2012. J Trauma Acute Care Surg 2015;78:1014-20. 
4 Care Quality Commission. Defence Medical Services Report June 2012. http://www. cqc.org.uk/sites/default/files/documents/20120621_dms_report_full_final.pdf

5 Allied Joint Publication 4-10(B) Allied Joint Medical Doctrine Ministry of Defence 28 July 2015. http://www.gov.uk/government/publications/allied-joint-medical-supportdoctrine-ajp-410

6 Mitchell TK, Smith GM. History of the Great War based on official documents by direction of the Historical Section of the Committee of Imperial Defence. Medical Services: Casualties and Medical Statistics of the Great War. London, HMSO; 1931.

7 Franklin, WM, eds. Official history of the second world war casualties and medical statistics. London: HMSO, 1972.

8 Roberts MJ, Fox MA, Hamilton-Davies C, et al. The experience of the intensive care unit in a British army field hospital during the 2003 gulf conflict. J R Army Med Corps 2003;149:284-90.

9 Rew DA, Clasper J, Kerr G. Surgical workload from an integrated UK Field Hospital during the 2003 Gulf Conflict. J R Army Med Corps 2004;150:99-106.

10 Ramalingam T. Extremity injuries remain a high surgical workload in a conflict zone: experiences of a British field hospital in Iraq, 2003. J R Army Med Corps 2004;150:187-90.

11 Russell R, Hodgetts T, Ollerton J, et al. The Operational Emergency Department Attendance Register (OPEDAR): a new epidemiological tool. J R Army Med Corps 2007:153:244-50

12 Smith J, Hodgetts T, Mahoney $P$, et al. Trauma governance in the UK defence Medical Services. J R Army Med Corps 2007;153:239-42.

13 Keene DD, Penn-Barwell JG, Wood PR, et al. Died of wounds: a mortality review. J R Army Med Corps 2016;162:355-60.

14 Inwald DP, Arul GS, Montgomery M, et al. Management of children in the deployed intensive care unit at Camp Bastion, Afghanistan. J R Army Med Corps 2014; 160:236-40.

15 Brodie S, Hodgetts TJ, Ollerton J, et al. Tourniquet use in combat trauma: UK military experience. J R Army Med Corps 2007;153:310-13.

16 Allcock E, Woolley $T$, Doughty $H$, et al. The clinical outcome of UK military personnel who received a massive transfusion in Afghanistan during 2009. J R Army Med Corps 2011;157:365-9.

17 Hodgetts TJ, Davies S, Russell R, et al. Benchmarking the UK military deployed trauma system. J R Army Med Corps 2007;153:237-8.

18 UK Armed Forces Deaths: Operational deaths post World War II. 3 September 1945 to 17 February 2016. Ministry of Defence. Defence Statistics (Health) dated 31 Mar 2016. http://www.gov.uk/government/statistics/uk-armed-forces-operationaldeaths-post-world-war-2-2016

19 Afghanistan and Iraq Amputation Statistics 7 October 2001-31 March 2016. Ministry of Defence. Defence Statistics (Health). 28 Jul 2016. http://www.gov.uk/ government/collections/uk-service-personnel-amputation-statistics-index

20 Types of Injuries Sustained by UK Service Personnel on OP HERRICK in Afghanistan 1 Apr 2006 to 30 Nov 2014. Ministry of Defence. Defence Statistics (Health). 25 Feb 2016 https://www.gov.uk/government/statistics/types-of-injuries-sustained-by-ukservice-personnel-on-operations-in-afghanistan-op-herrick-1-april-2006-to-30november-2014

21 Kowitz S, Bricknell MCM. Experiences as a medical adviser and director for NATO operations. Medical Corps International 2007;1:47-54.

22 Bricknell MCM, Beardmore CE. The context for planning military health services support. J R Army Med Corps 2011;157:S430-3

23 Bricknell MCM. Reflections on medical aspects of ISAF IX in Afghanistan. J R Army Med Corps 2007;153:44-51

24 Bricknell MCM, McCormack T. Military approach to medical planning in humanitarian operations. Br Med J 2005;330:1437-9.

25 Bricknell MCM, Williamson RHB. Medical planning and the estimate. J R Army Med Corps 2011;157(Suppl 4):S434-8.

26 Davies SL, Bricknell MCM. Developing an operational casualty estimate in a multinational headquarters to inform and drive medical resource allocation. US Army Med Dep J 2012:51-7.

27 Bricknell MCM, Jones FR, Hatzfeld JJ. Casualty estimation and medical resource planning. J R Army Med Corps 2011;157(Suppl 2):S439-43.

28 Bricknell MCM. Medical lessons from OPERATION MOSHTARAK Phase 2. J R Army Med Corps 2011;157(Suppl 4):S463-7.

29 Bricknell MCM, Cordell RF. Continuous improvement in healthcare support to operations. J R Army Med Corps 2011;157(Suppl 2):S460-2

30 Bonser $C D$, Fawcett JR. Operational medical force protection: the collective solution. J R Army Med Corps 2013;159:51-55.

31 Mahoney PF, Hodgetts TJ, Hicks I. The deployed medical director: managing the challenges of a complex trauma system. J R Army Med Corps 2011;157(Suppl 3): S350-6.

32 Henning J. The ethical dilemma of providing intensive care treatment to local civilians on operations. J R Army Med Corps 2009;155:84-86.

33 O'Reilly D. Proceedings of the DMS Medical Ethics Symposium. J R Army Med Corps 2011;157:405-10.

34 Cordell RF. Multinational medical support to operations: challenges, benefits and recommendations for the future. J R Army Med Corps 2012; 158:22-8.
35 Technical Arrangement between HQ US CENTCOM and PJHQ UK Regarding the Provision of Role 3 Medical Support at Bastion Joint Operation Base Afghanistan dated 19 Mar 2010.

36 Batham DR, Wall CM. An audit of the quality of deployed dmicp records on operation HERRICK 14. J R Army Med Corps 2012;158:213-16.

37 Cox AT, Linton TD, Lentaigne J, et al. A review of the documentation in the British Armed Forces electronic patient record following discharge from the Role 3 Hospital in Camp Bastion. J R Army Med Corps 2015;161:132-4.

38 Cox AT, Linton TD, Bailey $K$, et al. An evaluation of the burden placed on the General Internal Medicine team at the Role 3 Hospital in Camp Bastion by UK Armed Forces personnel presenting with symptoms resulting from previously identified disease. J R Army Med Corps 2016;162:18-22.

39 Bricknell MCM, Johnson AG. Forward medical evacuation. J R Army Med Corps 2011;157(Suppl 4)S444-8.

40 Parsons IT, Wheatley RJ, Carter P. Exercise ASKARI SERPENT: enabling clinical data collection during exercises and operations to support future contingency planning and assurance of category-based reporting systems. J R Army Med Corps 2016;162:50-55.

41 CORTISONE Programme Blueprint Document. Ministry of Defence 4 Dec 2015. http://www.gov.uk/government/publications/programme-cortisone

42 Bricknell MCM, dos Santos NM. Executing military medical operations. J R Army Med Corps 2011;157(Suppl 4):S457-9.

43 Cordell R, Cooney MS, Beijer D. Audit of the effectiveness of command and control arrangements for medical evacuation of seriously ill or injured casualties in Southern Afghanistan 2007. J R Army Med Corps 2008;154:227-30.

44 Nadin M, Mahoney PF. Focus on ... HOSPEXs introduction. J R Army Med Corps 2008;154:193.

45 Gill G, Butt P, Reade MC, et al. HOSPEX in the antipodes. J R Army Med Corps 2015;161:336-40.

46 Gibson C, Fletcher T, Clay K, et al. Foreign Medical Teams in support of the Ebola outbreak: a UK military model of pre-deployment training and assurance. J R Army Med Corps 2016;162:163-8.

47 Hodgetts TJ, Findlay S. Putting Role 1 first: the Role 1 capability review. J R Army Med Corps 2012;158:162-70.

48 Simpson RG. A better understanding of deployed role 1. J R Army Med Corps 2012;158:155.

49 Wheatley RJ. The Role 1 capability review: mitigation and innovation for Op HERRICK 18 and into contingency. J R Army Med Corps 2014;160:211-12.

50 Mercer SJ, Howell M, Simpson R. Simulation training for the Frontline-realistic preparation for Role 1 doctors. J R Army Med Corps 2010;156:87-9.

51 Martin-Bates AJ, Jefferys SE. General Duties Medical Officer Role 1 remote supervision in the era of Army Contingency Operations. J R Army Med Corps 2016;162:239-41.

52 Bricknell MCM, Hanhart N. Stability operations and the implications for military health services support. J R Army Med Corps 2007;153:18-21.

53 Connolly MJ. Health service support in the future operating environment 2035 J R Army Med Corps 2015;161:32-5.

54 Batham D, Finnegan $A$, Kiernan $M$, et al. Factors affecting front line casualty care in Afghanistan. J R Army Med Corps 2012;158:173-80.

55 Hawksley OJ, Jeyanathan J, Mears $\mathrm{K}$, et al. A survey of primary health care provision at a forward operating base in Afghanistan during operation HERRICK 10. J R Army Med Corps 2011;157:145-9.

56 Randall-Carrick J. Experiences of combat medical technician continuous professional development on operations. J R Army Med Corps 2012;158:263-68.

57 Parsons IT, Rawden MP, Wheatley RJ. Development of pre-deployment primary healthcare training for Combat Medical Technicians. J R Army Med Corps 2014;160:241-4.

58 Mahan JK. The future training of combat medical technicians-where next? J R Army Med Corps 2014;160:206.

59 Hodgetts T, Mahoney P, Mozumder A, et al. Care of civilians during military operations. Int/ J Dis Med 2005;3:3-24.

60 Walker N, Russell RJ, Hodgetts TJ. British military experience of pre-hospital paediatric trauma in Afghanistan. J R Army Med Corps 2010;156:150-3.

61 Woods KL, Russell RJ, Bree $S$, et al. The pattern of paediatric trauma on operations. J R Army Med Corps 2012;158:34-37.

62 Simpson RG, Wilson D, Tuck JJ. Medical management of captured persons. J R Army Med Corps 2014;160:4-8.

63 Moy RJ. Ethical dilemmas in providing medical care to captured persons on operations. J R Army Med Corps 2012;158:6-9.

64 McNeill-Love RMC. Commentary on CPERS. J R Army Med Corps 2012;158:9.

65 Thompson DF, Bricknell MCM. The Role of Medical Diplomacy in Stabilizing Afghanistan Thompson DF Defence Horizons. 2008;63:1-8.

66 Bricknell MCM, Thompson D. Roles for international military medical services in Stability Operations (Security Sector Reform). J R Army Med Corps 2007; 153:95-8.

67 Bricknell MCM, Grigson E-J. International military medical engagement with the indigenous health sector-Afghan Security Forces Medical Services. J R Army Med Corps 2011;157(Suppl 4):S468-72. 
68 Bricknell MCM, Gadd RDM. Roles for international military medical services in stability operations (reconstruction and development). J R Army Med Corps 2007;153:160-4.

69 Bricknell MCM, Cameron EA. International military medical engagement with the Indigenous Civilian Health Sector. J R Army Med Corps 2011;157(Suppl 4): S472-76.

70 Bulstrode C. Medcaps-do they work? J R Army Med Corps 2009;155:182-4.

71 Cameron EA. Do no harm - the limitations of civilian medical outreach and MEDCAP programmes based in Afghanistan. J R Army Med Corps 2011;157:209-11.

72 The military medical contribution to security and stabilisation (JDN 3/14). Ministry of Defence 18 Jun 2014. http://www.gov.uk/government/publications/ the-military-medical-contribution-to-security-and-stabilisation
73 Russell RJ, Hunt N, Delaney R. The mortality peer review panel: a report on the deaths on operations of UK Service personnel 2002-2013. J R Army Med Corps 2014;160:150-4.

74 Breeze J, Allanson-Bailey LS, Hunt NC, et al. Using computerised surface wound mapping to compare the potential medical effectiveness of Enhanced Protection Under Body Armour Combat Shirt collar designs. J R Army Med Corps 2015;161:22-6.

75 Breeze J, Allanson-Bailey LS, Hepper AE, et al. Demonstrating the effectiveness of body armour: a pilot prospective computerised surface wound mapping trial performed at the Role 3 hospital in Afghanistan. J R Army Med Corps 2015;161:36-41.

76 Bricknell MC, Hodgetts T, Beaton K, et al. Operation GRITROCK: the Defence Medical Services' story and emerging lessons from supporting the UK response to the Ebola crisis. J R Army Med Corps 2016;162:169-75.

77 Connolly MJ. Defence Medical Services concepts and doctrine 2014. J R Army Med Corps 2015;161:71-72. 